\title{
Jurema-Preta (Mimosa tenuiflora [Willd.] Poir.): a Review of its Traditional Use, Phytochemistry and Pharmacology
}

\author{
Rafael Sampaio Octaviano de Souza ${ }^{1}$, Ulysses Paulino de Albuquerque ${ }^{1 *}$, Júlio Marcelino \\ Monteiro $^{1}$ and Elba Lúcia Cavalcanti de Amorim ${ }^{2}$ \\ ${ }^{I}$ Departamento de Biologia; Universidade Federal Rural de Pernambuco; Rua Dom Manoel de Medeiros, s/n; \\ upa@db.ufrpe.br; 52171-900; Recife - PE - Brasil. ${ }^{2}$ Departamento de Ciências Farmacêuticas; Centro de Ciências \\ da Saúde; Universidade Federal de Pernambuco; Av. Prof. Arthur de Sá, s/n; 50740-521; Recife - PE - Brasil
}

\begin{abstract}
Numerous plant species are used throughout the world to achieve the modified states of conscientiousness. Some of them have been used for the therapeutic purposes, such as Mimosa tenuiflora (Willd) Poir. (family Mimosaceae) known as "jurema-preta", an hallucinogenic plant traditionally used for curing and divination by the Indians of northeastern Brazil. In this review, several aspects of the use, phytochemistry, and pharmacology of this plant are considered.
\end{abstract}

Key words: Ethnopharmacology, hallucinogenic plants, natural products, entheogen

\section{INTRODUCTION}

Several terms have been used to describe the substances that provoke alterations in the human mind: psychotropic, hallucinogen, psychomimetic, schizogen, eidetic, psychotic, psychogen, and psychodisleptic are just some of them (Schultes, 1994). The most recent term is entheogen ("God inside us") (Fericgla, 1994 a,b), coined in 1978 by a group of scientists led by Gordon Wasson (Mota and Barros, 2002).

In northeastern Brazil, some indigenous tribes make use of "jurema wine", or "ajucá", as a "miraculous drink". It is generally made from the plants of the Mimosaceae family, mainly "juremapreta" (For example: Mimosa tenuiflora (Willd) Poir.) (Albuquerque, 1997, 2001, 2002; Camargo, 2002). The substance responsible for its psychoactivity is a tryptaminic alkaloid called N,N-dimetyltryptamine (DMT) (Fig. 1). It is inactive when administered orally (MeckesLozoya et al., 1990a).

In the African-Brazilian cults, M. tenuiflora is also used to cure the infections and treat the inflammations (Albuquerque and Chiappeta, 1994). The wood is used in Honduras, Guatemala, El Salvador, Nicaragua, Colombia, and Venezuela to make a highly caloric charcoal (Andrade-Lima, 1954). In all of these countries, as well as in Panama, this species is used in the agroforestry management. In Mexico (especially in Oxaca and Chiapas) the wood is used for the charcoal, to construct the living (green) fences, and for the demarcation of the plots of the land, and animal pens (Camargo-Ricalde, 2000; Rivera-Arce et al., 2007a). The tannins extracted from this species are used in the paints and for tanning (CamargoRicalde, 2000). In Brazilian Northeast, it is said that the bark of M. tenuiflora can cure the fatigue, or strengthen the uterus (Duke, 2000).

\footnotetext{
${ }^{*}$ Author for correspondence
} 


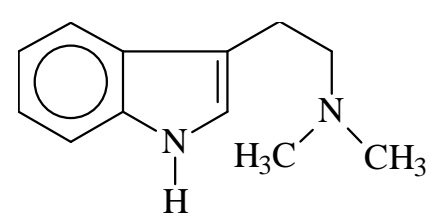

Figure 1 - N,N-dimetyltryptamine (DMT)

The aim of this paper was to present a brief review of the phytochemistry, pharmacology, and traditional uses of $M$. tenuiflora, as well as focus on its role in the cultural and religious manifestations among the indigenous groups in Brazil. The main source of information for this study was previously published literature on Mimosa tenuiflora (Willd.) Poir. Data were also obtained from NAPRALERT (Natural Products Alert), a computerized database maintained by the University of Illinois in Chicago. This database contains information concerning the medicinal uses of many natural products, including their ethnomedical, pharmacological, and phytochemical profiles.

\section{Historical and Ethnographic Aspects of the use of "Jurema" (Mimosa tenuiflora [Willd.] Poir.)}

Mimosa tenuiflora, as well as other species of the Mimosa genus, have been used by the indigenous tribes in the cults in the northeastern Brazil since long before Portuguese colonization. After the colonization it was also utilized by the Afrobrazilians. The plant is used in making a hallucinogen drink that is called "jurema wine" by the indigenous groups such as the Truka (from the Assunção Island in Cabrobó, Pernambuco state) and the Kambiwa (from Ibimirim, Inajá, and Floresta, Pernambuco state). Other groups call it "jurema". The Pankararu (Brejo dos Padres Tacaratu, Jatobá, and Petrolândia, Pernambuco state) identify the drink as "ajucá"; the Atikum (Serra do Umã, sertão of Pernambuco) and the Kambiwa call it "anjucá" (Grünewald, 2002). There are at least nineteen different species known as "jurema" (see Table 1). One element in common among these plants (or at least to their genera) is the presence of alkaloids (Herz, 2001; Seigler, 2003), active principles related to the ritual use of these plants by the indigenous people of the northeastern Brazil. In addition to $M$. tenuiflora, these compounds have also been isolated from $M$. ophtalmocentra (Batista and Almeida, 1997). Some of the species cited in Table 1, however, principally those known as "jurema-branca" (white jurema), do not contain tryptaminic alkaloids (Ott, 2002).

Most indigenous users shave the root or stem bark of M. tenuiflora to prepare the drink (Lima, 1946; Sangirardi, 1989; Mota and Barros, 1990; 2002). Among the Kariri-Xoko Indians, these bark shavings are extracted from the forest specimens (that should only be seen or touched by those "initiated" by the tribe's older wisemen, under the restriction of the sexual taboo). The bark is then cooked in the water for a long period of time in a clay pot made especially for the occasion, until the drink acquires a thick consistency and a dark coloration (Mota and Barros, 2002). In practically all the indigenous rituals involving "jurema", tobacco and candles are used. Today, these rituals are practiced in a festival called Toré, in which the Indians worship the religious entities, including the mythical ancestors, and sing the traditional songs (Grünewald, 2002).

Very little information is available concerning "jurema" use among the Afro-brazilian cults, as its use is usually a well-kept secret. The preparation appears to consist basically of cooking the plants from different species, and then adding them to "cachaça" (a sugar cane distillate) or red wine. The product is kept in the dark receptacles, made of the clay or glass, for a variable number of the days (Albuquerque, 2002). Some of the plants added to the drink have confirmed the toxic effects. The final effect of the beverage can vary greatly among the preparations (Albuquerque, 1997). The African-Brazilian cults that use the plants with the common name "jurema" are distributed throughout several Brazilian states. 
Table 1 - Plants known as "jurema" in Brazil (Albuquerque, 1997, 2002).

\begin{tabular}{|c|c|}
\hline Family/Scientific Name & Popular names \\
\hline $\begin{array}{c}\text { Asteraceae } \\
\text { Eupatorium inulaefolium H.B.K. }\end{array}$ & Jurema, jurema-branca. \\
\hline $\begin{array}{c}\text { Mimosaceae } \\
\text { Acacia piahuiensis Benth. }\end{array}$ & Jurema, jurema-branca. \\
\hline A. riparia Kunth & Jurema, jurema-branca. \\
\hline A. bahiensis Benth. & Jurema, jurema-branca. \\
\hline Chloroleucon foliolosum (Benth.) G. P. Lewis & Jurema, jurema-branca. \\
\hline C. tortum (Mart.) Pitter & Jurema. \\
\hline C. dumosun (Benth.) G. P. Lewis & Jurema, jurema-branca. \\
\hline Mimosa acutistipula Benth. & Jurema-preta, jurema, jurema-branca, jureminha. \\
\hline M. arenosa (Willd) Poir. & Jurema, jurema-branca, jureminha. \\
\hline M. ophtalmocentra Mart. Ex Benth. & Jurema, jurema-preta, jurema-mirim. \\
\hline M. tenuiflora (Willd.) Poir. & Jurema-preta, jurema. \\
\hline M. verrucosa Benth. & $\begin{array}{l}\text { Jurema, jurema-branca, jureminha, } \\
\text { jurema-de-oleiras, jurema-vermelha. }\end{array}$ \\
\hline M. adenophylla Taub. var. mitis Barneby & Jurema, jurema-cor-de-rosa. \\
\hline Parapiptadenia sp. & Jurema, jurema-branca. \\
\hline Piptadenia stipulacea (Benth.) Ducke & Jurema, jurema-branca. \\
\hline P. moniliformis Benth & Jurema-preta. \\
\hline Pithecolobium diversifolium Benth. & Jurema-branca. \\
\hline $\begin{array}{l}\text { Verbenaceae } \\
\text { Lippia chamissonis Die. }\end{array}$ & Jurema, jureminha. \\
\hline Vitex agnus-castus $\mathrm{L}$. & Jureminha, jurema-branca, jurema. \\
\hline
\end{tabular}

\section{Secondary Metabolites of Mimosa tenuiflora (Willd.) Poir.}

The phytochemistry of $M$. tenuiflora has attracted considerable interest, mainly due to the presence of indole alkaloids and tannins (proanthocyanidins) (Rivera-Arce et al., 2007a). However, phytochemical reports on others classes of the compounds that may be present are rare.

Alkaloids: Two indole alkaloids have been isolated from "jurema": 5-hydroxy-tryptamine, and N,N-dimetyltryptamine (Meckes-Lozoya et al., 1990a) (Fig. 1). The latter is also found in the root bark (Melo and Bandeira, 1961), and is linked to its hallucinogen use, as mentioned above. The alkaloid N,N-dimetyltryptamine was apparently detected for the first time by Gonçalves de Lima and his team, after a visit to the Pancararu village in Brejo dos Padres (Pernambuco state, northeastern Brazil). The substance isolated was called nigerine (Lima, 1946). Ott (2002), however, suggested that this product could be an impure form of N,N-dimetyltryptamine. Vepsäläinen et al. (2005) performed one phytochemical study of this species with advanced instrumentation and methodologies, particularly ${ }^{1} \mathrm{H}-{ }^{13} \mathrm{C}$ nuclear magnetic resonance (NMR) and liquid chromatography-mass spectrometry (LC-MS) under mild acidic pH. A new phytoindole, Yuremamine, was isolated from the stem bark of M. tenuiflora in this study (Fig. 2).

\section{Chalcones}

Other studies demonstrated the presence of two chalcones: kukulkan A (2',4'-dihydroxy-3',4dimetoxychalcone); and kukulkan B (2',4',4- 
trihydroxy-3'-metoxychalcone)(Camargo-Ricalde, 2000) (Fig. 3).

\section{Steroids and terpenoids}

Among the several substances three steroids were isolated from the stem bark of $M$. tenuiflora: campesterol-3-O-beta-D-glucopyranosyl, stigmasterol-3-O-beta-D-glucopyranosyl, and beta-sitosterol-3-O-beta-D-glucopyranosyl (Anton et al., 1993). Three saponins have also been identified: mimonoside $\mathrm{A}$, mimonoside $\mathrm{B}$, and mimonoside C (Fig. 4) (Anton et al., 1993; Jiang et al., 1991a; Jiang et al., 1992). Anton et al. (1993) recorded the presence of the triterpenoid lupeol.

\section{Phenoxychromones}

Five 2-phenoxychromones ("uncommon" flavonoids), the tenuiflorin A [5,7-dihydroxy-2-(3hydroxy-4-methoxyphenoxy)-6

methoxychromone], tenuiflorin B [5,7-dihydroxy2-(4-hydroxy-3-methoxyphenoxy)-6methoxychromone] and tenuiflorin $C$ [5,7dihydroxy-2-(3-hydroxy-4-methoxyphenoxy)chromone], along with 6-demethoxycapillarisin and 6-demethoxy-4'-O-methylcapillarisin were isolated from the leaves of M. tenuiflora (Fig. 5). These uncommon "flavonoids" exhibited an unusual ether linkage between the $\mathrm{B}$ and $\mathrm{C}$ ring (Léon et al., 2004).

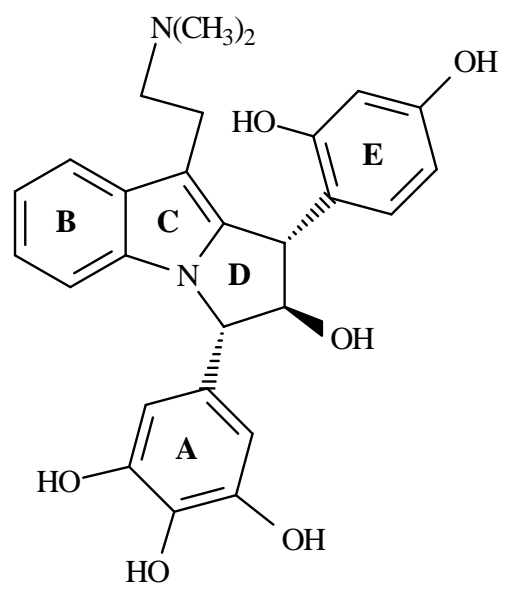

Figure 2 - Yuremamine from the stem bark of Mimosa tenuiflora (Willd.) Poir.<smiles>[R]c1ccc(/C=C/C(=O)c2ccc(O)c(OC)c2O)cc1</smiles>

Kukulkan A: $\mathrm{R}=\mathrm{OCH}_{3}$

Kukulkan B: $\mathrm{R}=\mathrm{OH}$

Figure 3 - Chalcones isolated from the stem bark of Mimosa tenuiflora (Willd.) Poir. 


\section{Pharmacological Studies of the Extracts}

\section{Antimicrobial activity}

Tables 2 and 3 show results of the experiments undertaken to test for any antimicrobial activity of the substances from the bark of $M$. tenuiflora. Tannins are probably responsible for most of this activity (Meckes-Lozoya et al., 1990b). An ethanol extract $(95 \%)$ was active against
Micrococcus luteus and Bacillus subtilis (Heinrich et al., 1992). Table 3 lists the species of the fungi (Microsporum canis, Microsporum gypseum, Trichophyton mentagrophytes, Trichophyton rubrum, and Chaetomium indicum) against which the activity was observed. The substances extracted with ethanol (95\%) were also effective against Candida albicans (Lozoya et al., 1989).

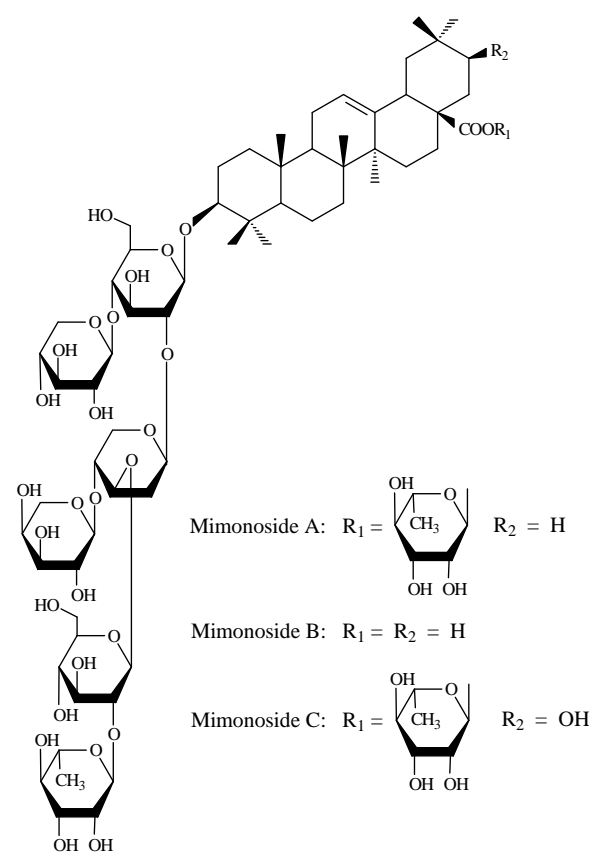

Figure 4 - Triterpenoids saponins isolated from the stem bark of Mimosa tenuiflora (Willd.) Poir.

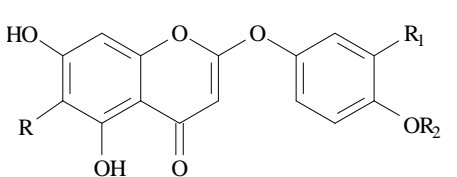

Tenuiflorin A: $\mathrm{R}=\mathrm{OMe}, \mathrm{R}_{1}=\mathrm{OH}, \mathrm{R}_{2}=\mathrm{Me}$

Tenuiflorin $\mathrm{B}: \mathrm{R}=\mathrm{R}_{1}=\mathrm{OMe}, \mathrm{R}_{2}=\mathrm{H}$

Tenuiflorin $\mathrm{C}: \mathrm{R}=\mathrm{H}, \mathrm{R}_{1}=\mathrm{OH}, \mathrm{R}_{2}=\mathrm{Me}$

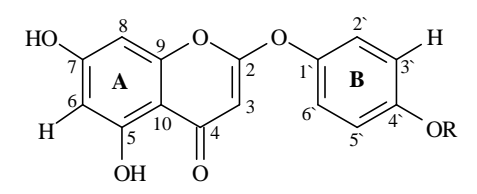

6-Demethoxycapilarisin: $\mathrm{R}=\mathrm{H}$

6-Demethoxy-4`-O-methylcapilarisin: $\mathrm{R}=\mathrm{Me}$

Figure 5 - 2-Phenoxychromones isolated from the leaves of Mimosa tenuiflora (Willd.) Poir. 
Table 2 - Antibacterial activity related from Mimosa tenuiflora (Willd.) Poir.

\begin{tabular}{|c|c|c|}
\hline Extract / Active dose & Results/ Tested microorganism & Ref. \\
\hline $\begin{array}{l}\text { Buthanol } \\
5.0 \mathrm{mg} / \text { well }\end{array}$ & Staphylococcus aureus & (Meckes-Lozoya et al., 1990b) \\
\hline $\begin{array}{l}\text { Buthanol } \\
15.0 \mathrm{mg} / \text { well }\end{array}$ & Escherichia coli & “ \\
\hline $\begin{array}{l}\text { Methanol } \\
5.0 \mu \mathrm{g} / \text { well }\end{array}$ & Staphylococcus aureus & “ \\
\hline $\begin{array}{l}\text { Methanol } \\
30.0 \mu \mathrm{g} / \text { well }\end{array}$ & Escherichia coli & “ \\
\hline $\begin{array}{l}\text { Ethyl Acetate } \\
5.0 \mathrm{mg} / \text { well }\end{array}$ & Escherichia coli & “ \\
\hline $\begin{array}{l}\text { Ethyl Acetate } \\
10.0 \mathrm{mg} / \mathrm{well}\end{array}$ & Staphylococcus aureus & “ \\
\hline $\begin{array}{l}\text { Ethanol }(95 \%) \\
\text { MIC }>10.0 \mu \mathrm{g} / \mathrm{mL}\end{array}$ & $\begin{array}{l}\text { Staphylococcus epidermidis and } \\
\text { Acinetobacter calcoaceticus }\end{array}$ & (Lozoya et al., 1989) \\
\hline $\begin{array}{l}\text { Ethanol }(95 \%) \\
\text { MIC } 10.0 \mu \mathrm{g} / \mathrm{mL}\end{array}$ & $\begin{array}{l}\text { Staphylococcus aureus and } \\
\text { Micrococcus luteus }\end{array}$ & “ \\
\hline $\begin{array}{l}\text { Ethanol }(95 \%) \\
\text { MIC } 20.0 \mu \mathrm{g} / \mathrm{mL}\end{array}$ & $\begin{array}{l}\text { Escherichia coli and } \\
\text { Klebsiella pneumoniae }\end{array}$ & “ \\
\hline $\begin{array}{l}\text { Ethanol }(95 \%) \\
\text { MIC } 40.0 \mu \mathrm{g} / \mathrm{mL}\end{array}$ & Pseudomonas aeruginosa & “ \\
\hline $\begin{array}{l}\text { Ethanol }(95 \%) \\
5.0 \mu \mathrm{g} / \mathrm{disc}\end{array}$ & Escherichia coli & (Heinrich et al., 1992) \\
\hline $\begin{array}{l}\text { Ethanol }(95 \%) \\
10.0 \mu \mathrm{g} / \text { disc }\end{array}$ & Bacillus subtilis & “ \\
\hline $\begin{array}{l}\text { Ethanol }(95 \%) \\
20.0 \mu \mathrm{g} / \mathrm{disc}\end{array}$ & Micrococcus luteus & “ \\
\hline
\end{tabular}

\section{Antiinflammatory and healing action}

Tellez and Dupoy de Guitard (1990) demonstrated the effectiveness of $M$. tenuiflora in the topical treatment of the eczema ( $10 \%$ concentration), as well as against the inflammations (as a powder made from the dry bark) in the humans. In a similar experiment, the use of the dry bark of $M$. tenuiflora proved to be effective in wound healing (Dupoy de Guitard, 1990) and in the treatment of venous leg ulceration disease (Rivera-Arce et al., 2007b).

\section{Antispasmolytic action}

Meckes-Lozoya et al. (1990b), using a spray of the bark extract, observed (Table 4): the inhibition of the intestinal peristalsis due to a relaxation of the ileum smooth muscle tissue; an increase in the muscular tonus and in the frequency of the contractions of the uterus segments; and an increase in the muscular tonus of the stomach walls. All these experiments were performed with the rats and guinea pigs. The butanol extract was the most efficient, and contained the most 
alkaloids (Meckes-Lozoya et al., 1990b). A fraction containing the indolalkylamine and three other smaller bases were responsible for inhibiting the peristaltic reflex of the intestine, resulting in the relaxation of the ileum observed in the guinea pigs (Meckes-Lozoya et al., 1990c).

\section{Hemolytic activity}

Mekces-Lozoya et al. (1990b) reported the hemolytic activity of the raw extracts of the stem bark (Table 4). Triterpenic saponines, the substances considered responsible for this activity, cause membrane rupture in the erythrocytes (Banerji et al., 1981). Studies undertaken in 1992 detected a hemolytic effect in low concentrations of a methanol extract containing alkaloids, and a haemagglutinant effect in high doses (Heinrich et al., 1992).

Table 3 - Antifungical activity related from Mimosa tenuiflora (Willd.) Poir.

\begin{tabular}{|c|c|c|}
\hline Extract / Dose & Results/ Tested microorganism & Ref. \\
\hline $\begin{array}{ll}\text { Ethanol } & (95 \%) \\
\text { MIC } & 10.0 \\
\mu \mathrm{g} / \mathrm{Ml} & \end{array}$ & $\begin{array}{l}\text { Microsporum canis, Microsporum gypseum, Trichophytor } \\
\text { mentagrophytes, Trichophyton rubrum and Chaetomium indicum }\end{array}$ & (Lozoya et al., 1989) \\
\hline $\begin{array}{l}\text { Ethanol }(95 \%) \\
10.0 \mu \mathrm{g} / \mathrm{disc}\end{array}$ & Penicillium oxalicum & (Heinrich et al., 1992) \\
\hline $\begin{array}{l}\text { Ethyl Acetate } \\
30.0 \mathrm{mg} / \text { well }\end{array}$ & Candida albicans & $\begin{array}{l}\text { (Meckes-Lozoya et al., } \\
1990 \mathrm{~b})\end{array}$ \\
\hline $\begin{array}{l}\text { Ethanol }(95 \%) \\
\text { MIC } \quad 70.0 \\
\mu \mathrm{g} / \mathrm{mL}\end{array}$ & Candida albicans & (Lozoya et al., 1989) \\
\hline
\end{tabular}

Table 4 - Biological activities from crude extracts of Mimosa tenuiflora (Willd.) Poir. (1) Meckes-Lozoya et al. (1990b); (2) Tellez and Dupoy de Guitard (1990); (3) Meckes-Lozoya et al. (1990c).

\begin{tabular}{|c|c|c|c|c|}
\hline Activity & Tested in & $\begin{array}{l}\text { Extract/ } \\
\text { concentration }\end{array}$ & Result & Ref. \\
\hline \multirow[t]{3}{*}{ Hemolytic } & Erythrocytes & $\begin{array}{l}\text { Buthanol } \\
250.0 \mu \mathrm{g} / \mathrm{mL}\end{array}$ & $74 \%$ of hemolyse & 1 \\
\hline & & $\begin{array}{l}\text { Ethyl Acetate } \\
250.0 \mathrm{~g} / \mathrm{mL}\end{array}$ & $48 \%$ of hemolyse & \\
\hline & & $\begin{array}{l}\text { Methanol } \\
500.0 \mu \mathrm{g} / \mathrm{mL}\end{array}$ & $68 \%$ of hemolyse & \\
\hline \multirow[t]{2}{*}{ Wound healing } & $\begin{array}{l}\text { Adult human extern } \\
\text { use }\end{array}$ & $10 \%$ & Active & 2 \\
\hline & & $\begin{array}{l}\text { Not related } \\
\text { (powder) }\end{array}$ & Active & \\
\hline
\end{tabular}


(Cont. Table 4)

\begin{tabular}{|c|c|c|c|c|}
\hline Activity & Tested in & $\begin{array}{l}\text { Extract/ } \\
\text { concentration }\end{array}$ & Result & Ref. \\
\hline \multirow[t]{4}{*}{$\begin{array}{l}\text { Alteration in } \\
\text { muscular tonus }\end{array}$} & $\begin{array}{l}\text { Guinea pig and mouse } \\
\text { (all the tests) }\end{array}$ & $\begin{array}{l}\text { Buthanol } \\
30.0 \mu \mathrm{g} / \mathrm{mL}\end{array}$ & $\begin{array}{l}\text { Increase of muscular tonus and the } \\
\text { frequency of contraction of the uterus. } \\
\text { Active in stomach (increase muscular } \\
\text { tonus in rats and relaxation in guinea pig) } \\
\text { and ileum (relaxation) }\end{array}$ & 1 \\
\hline & & $\begin{array}{l}\text { Ethyl Acetate } \\
30.0 \mu \mathrm{g} / \mathrm{mL}\end{array}$ & $\begin{array}{l}\text { Increase of muscular tonus and the } \\
\text { frequency of contraction of the uterus. } \\
\text { Active in stomach (increase muscular } \\
\text { tonus in rats and relaxation in guinea pig) } \\
\text { and ileum (relaxation) }\end{array}$ & \\
\hline & & $\begin{array}{l}\text { Methanol } \\
30.0 \mu \mathrm{g} / \mathrm{mL}\end{array}$ & $\begin{array}{l}\text { Increase of muscular tonus and the } \\
\text { frequency of contraction of the uterus. } \\
\text { Active in stomach (increase muscular } \\
\text { tonus in rats and relaxation in guinea pig) } \\
\text { and ileum (relaxation) }\end{array}$ & \\
\hline & Guinea pig & $\begin{array}{l}\text { alkaloid crude } \\
\text { fraction } \\
100.0 \mu \mathrm{g} / \mathrm{mL} \\
\text { alkaloid crude } \\
\text { fraction } \\
25 \mu \mathrm{g} / \mathrm{mL} \text { and } \\
35 \mu \mathrm{g} / \mathrm{mL}\end{array}$ & Inhibition of the peristaltic reflex (ileum). & 3 \\
\hline
\end{tabular}

\section{Pharmacological Studies on Pure Compounds Isolated from Mimosa tenuiflora (Willd.) Poir.}

\section{Hallucinogenic action}

One of the species' most important biological activities is related to its use in religious rituals. The hallucinogenic effect that accompanies the use of "jurema" is similar to that of LSD-25, yet apparently of faster effect and shorter duration. Mydriasis and arterial hypertension are notably intense (Corbett, 1977). The psychic effects have been described by Matos (1983) as: “(...) anxiety, dizziness, 'hollow head' or airiness, 'waves' of tickles passing through the muscles. Next, there is a state of 'daydreaming', with opaque vision and very strong colors and an apparent visual sharpening. Hallucinations follow, along with an accentuated visual background; perception becomes very distorted and there might be delirium."

The pharmacological studies demonstrated that the hallucinogenic effect of N,N-dimetyltryptamine, when administered orally, was inhibited by the action of monoamino oxidases (MAO), insoluble enzymes found in the mitochondria (Corbett, 1977) that catalyzed the removal of an amino group alkaloid (Craig and Stitzel, 1986). For the hallucinatory effects to occur, it is also necessary to ingest the substances containing MAO inhibitors (such as $\beta$-carbolines), which will then permit the action of $\mathrm{N}, \mathrm{N}$-dimetyltryptamine (Schultes and Hofmann, 1980).

Sangirardi Jr. (1989) reported having taken cauim (a preparation made with "cachaça" and "jurema") several times, asserting that the "jurema" intensify the effect of the alcohol, giving a sensation of the happiness and peace, the sharpening of the vision and audition in the moments of relative silence, the latter effect being at times unpleasant. It caused drowsiness and heavy sleeping, resulting dreams and nightmares. This was followed by a strong hangover as well as slight tachycardia and considerable laziness. Albuquerque (1997), however, reported a euphoric state after the ingestion, as well as sweating (abundant at times), facial redness, and passing dizziness. 
These phenomena could be explained by the fact that $\beta$-carbolinas, which could be formed endogenously from the basic tryptamines such as 5-hydroxy-tryptamine (serotonine) (Calaway, 1988; Calaway, 1994), were found in M. tenuiflora (Meckes-Lozoya et al., 1990a). The presence of these substances can result in MAO inhibition, which may lead to an increase in the amount of catecholamine in the central nervous system, provoking euphoric effects (Corbett, 1977). According to Ott (2002), there may be MAO inhibitors in the "jurema preta" extract, which would explain the observed effects. Nevertheless, the "jurema wine" is potentially visionary per se. The inactivity of some preparations, might be due to insufficient dosage. Experimental studies are necessary to test this hypothesis.

\section{CONCLUSIONS}

The information presented here allow some conclusions with respect to the popular uses of "jurema" for the treatment of infections (Heinrich et al., 1992), treating minor burns, lesions, and eczemas (Tellez and Dupoy de Guitard, 1990), and for its antimicrobial activity (Lozoya et al., 1989; Meckes-Lozoya et al., 1990b). However, several other reported uses have not been examined: effectiveness against the hair loss, headaches, and toothaches; internal problems such as stomach acidity, gastritis, peptic and duodenal ulcers, colitis, and hemorrhoids; and herpes, acne, as well as parasite-related diseases (Camargo-Ricalde, 2000).

Although various aspects of the hallucinogenic effects of "jurema" have been shown, more studies would still be necessary to complete the knowledge of this plant. For example, there is no firm evidence yet that the drink is hallucinogenic per se, as suggested by Ott (2002), because its preparation is a consequence of the distinct cultural experiences. Perhaps an explanation can be found in the fact that the intensity of the effect seems to vary according to the different ingredients used by the different cultures. These different preparations represent not only regional influences, but also a wider interchange among the indigenous and African-Brazilian cultures. This interchange is clearly expressed in the preparation of the African-Brazilian beverage with the addition of alcohol and several other plant species
(Albuquerque, 2001). As such, the different preparations may be responsible for the diverse manifestations recorded.

More studies are necessary to determine the activity of N,N-dimetyltryptamine in the human body, as well as its interactions with other substances. There are studies available on the interactions of $\beta$-carbolines with $\mathrm{N}, \mathrm{N}$ dimetyltryptamine. There is still a need for more in-depth ethno-pharmacological studies on the traditional preparation of "jurema" beverages, and more detailed in loco observations.

\section{ACKNOWLEDGEMENTS}

We would like to thank Prof. J. M. Barbosa-Filho (Laboratório de Tecnologia Farmacêutica, Universidade Federal da Paraíba), for his support in the bibliographic survey using the NAPRALERT database. To CNPq for the financial support and grant given to U.P. Albuquerque.

\section{RESUMO}

Numerosas espécies de plantas são usadas para alterar estados de consciência. Algumas são utilizadas para fins terapêuticos, como Mimosa tenuiflora (Willd) Poir. (Mimosaceae) conhecida como "jurema-preta", uma planta alucinógena, tradicionalmente utilizada pelos índios no nordeste do Brasil. Nesta revisão, são considerados diversos aspectos do uso, fitoquímica e farmacologia desta planta.

\section{REFERENCES}

Albuquerque, U. P. (1997), Etnobotânica de uma bebida cerimonial no Nordeste do Brasil. Rev Bras Farm., 78, 86-89.

Albuquerque, U. P. (2001), The use of medicinal plants by the cultural descendants of african people in Brazil. Acta Farm Bonaerense, 20, 139-144.

Albuquerque, U. P. (2002), A jurema nas práticas dos descendentes culturais do africano no Brasil. In-As muitas faces da Jurema - de espécie botânica à divindade afro-indígena. Mota, C. N. and Albuquerque, U. P., eds. Edições Bagaço, Recife.

Albuquerque, U. P. and Chiappeta, A. A. (1994), O uso de plantas e a concepção de doença e cura nos cultos afro-brasileiros. Ciência and Trópico, 22, 197-209. 
Andrade-Lima, D. (1954), Contribution to the study of flora of Pernambuco, Brasil. Monografia; Universidade Rural de Pernambuco, Brasil.

Anton, R.; Jiang, Y.; Weniger, B.; Becker, J. P. and Rivier, L. (1993), Pharmacognosy of Mimosa tenuiflora (Willd.) Poiret. J. Ethnopharmacol., 38, 153-157.

Banerji, R.; Prakash, D.; Misra, G. and Nigam, S. K. (1981), Cardiovascular and hemolytic activity of Saponins. Indians Drugs, 52, 121-124.

Batista, L. M. and Almeida, R. N. (1997), Central effects of the constituents of Mimosa opthalmocentra Mart. ex Benth. Acta. Farm. Bonaerense, 16, 83-86.

Callaway, J. C. (1988), A proposed mechanism for the visions of dream sleep. Medical Hypotheses, 26, 119124.

Callaway, J. C. (1994), $\beta$-Carbolinas endógenas y otros alcaloides indólicos en los mamíferos. In-Plantas, Chamanismo y Estados de Consciencia; Fericgla, J. M., ed., Barcelona, La Liébre de Marzo S.L., Barcelona, pp. 197-230.

Camargo, M. T. L. A. (2002), Jurema (Mimosa hostilis Benth.) e sua relação com os transes nos sistemas de crenças afro-brasileiros. In-As muitas faces da Jurema - de espécie botânica à divindade afroindígena. Mota, C. N. and Albuquerque, U. P., eds., Edições Bagaço, Recife, pp. 151-170.

Camargo-Ricalde, S. L. (2000), Descripción, distribución, anatomía, composición química y usos de Mimosa tenuiflora (Fabaceae-Mimosoideae) en México Revista Biologica Tropical, 48, 939-954.

Corbett, C. E. (1977), Farmacodinâmica. Editora Guanabara Koogan, Rio de Janeiro.

Craig, C. R. and Stitzel, R. E. (1986), Farmacologia Moderna. Livraria Carioca, São Paulo.

Duke, J. A. (2000), Handobook of Medicinal Herbs, CRC Press, INC., Florida.

Fericgla, J. M. (1994a), Alucinógenos ou adapatógenos inespecíficos. In-Plantas, Chamanismo y Estados de Consciencia, ed., Barcelona, La Liébre de Marzo S.L., Barcelona, pp. 231-252.

Fericgla, J. M. (1994b), Prefácio. In: Plantas, Chamanismo y Estados de Consciencia; Fericgla, J. M., (ed.). Barcelona, La Liébre de Marzo S.L., Barcelona, pp. 7-15.

Grünewald, R. A. (2002), A jurema no "Regime de índio": o caso aticum. In-As muitas faces da Juremade espécie botânica à divindade afro-indígena. Mota, C. N.; Albuquerque, U. P., eds., Edições Bagaço, Recife, pp. 97-124.

Heinrich, M.; Kuhnt, M.; Wright, C. W.; Rimpler, H.; Phillipson, J. D.; Schandelmaier, A.; and Wargurst, D. C. (1992), Parasitological and Microbiological Evaluation of Mixe Indian Medicinal Plants (Mexico). J Ethnopharmacol., 36, 81-85.

Herz, W. (2001), Chemistry of eupatoriinae. Biochem. Syst. Ecol., 29, 1115-1137.
Jiang, Y. L.; Massiot, G.; Lavaud, C.; Teulon, J. M.; Guechot, C.; Haag-Berrurier, M. and Anton, R. (1991a), Triterpenoid glycosides from the bark of Mimosa tenuiflora. Phytochemistry, 30, 2357-2360.

Jiang, Y. L.; Haag-Berrurier, M.; Anton, R.; Massiot, G.; Lavaud, C.; Teulon, J. M. and Guechot, C. (1991b), Structure of a new saponin from the bark of Mimosa tenuiflora. J. Nat. Prod., 54, 1247-1253.

Jiang, Y. L.; Weniger, B.; Haag-Berrurier, M.; Anton, R.; Beck, J. P. and Italiano, L. (1992), Effects of Saponins from Mimosa tenuiflora on Lymphoma Cells and Lymphocytes. Phytoter Res, 6, 310-313.

León, L.; Maldonado, E.; Cruz, A. and Ortega, A. (2004), Tenuiflorins A-C: new 2-phenoxychromones from the leaves of Mimosa tenuiflora (Willd.) Poir. Planta Med., 70, 536.

Lima, O. G. (1946), Observações sobre o "Vinho da Jurema" utilizado pelos índios Pancarú de Tacaratu (Pernambuco). Arquivos do Instituto de Pesquisas Agronômicas, 4, 45-86.

Lozoya, X.; Navarro, V.; Arnason, J. T. and Kourany, E. (1989), Experimental evaluation of Mimosa tenuiflora (Willd.) Poir. (Tepeschohuite) I. screening of the antimicrobial properties of bark extracts. Archivos de Investigación Medica, 20, 87-93.

Matos, F. J. A. (1983), Efeitos psicotrópicos de plantas brasileiras Ciência e Cultura, 35, 432-434.

Meckes-Lozoya, M.; Lozoya, X.; Marles, R.; SoucyBreau, C. and Avalokitesvarasen, A. J.; (1990a), N,N-Dimethyltryptamine alkaloid in Mimosa tenuiflora bark (Tepescohuite). Archivos de Investigación Medica, 21, 175-177.

Meckes-Lozoya, M.; Lozoya, X.; Gonzalez, J. (1990b), Propiedades farmacológicas in vitro de algunos extractos de Mimosa tenuiflora (tepescohuite). Archivos de Investigacion Medica, 21, 163-169.

Meckes-Lozoya, M.; Lozoya, X.; Gonzalez, J. and Martinez, M. (1990c), Efecto producido por la fracción de alcaloides de Mimosa tenuiflora (tepescohuite) sobre el reflejo peristáltico del ileón del cobayo. Archivos de Investigación Medica, 21, 171-174.

Melo, A. C. and Bandeira, J. A. (1961), . Contribuição ao estudo químico e farmacológico do alcalóide da Jurema Preta (Mimosa hostilis Benth). Anais da Faculdade de Medicina da Universidade do Recife, 21, 9-33.

Mota, C. N.; and Barros, J. F. P. (1990), Jurema: blackindigenous drama and representations. InEthnobiology: Implications and Applications. First International Congress of Ethnobiology; Posey, D. A.; Overall, W., eds., Museu Paraense Emílio Goeldi, Belém, pp. 171-180. 
Mota, C.N. and Barros, J.F.P. (2002), O complexo da jurema: representações e drama social negroindígena. In-As muitas faces da Jurema - de espécie botânica à divindade afro-indígena. Mota, C. N. and Albuquerque, U. P., eds., Edições Bagaço, Recife, pp. 19-60.

NAPRALERT $^{\text {SM }}$ (Natural Product Alert), Department of Medicinal Chemistry and Pharmacognosy, College of Pharmacy of the University of Illinois at Chicago. Funcional foods for health. Available in http://www.ag.uiuc.edu/\% 7Effh/ napra.html.

Ott, J. (2002), Pharmahuasca, anahuasca e juremapreta: farmacologia humana de DMT oral mais harmine. In-O uso ritual da ayahuasca; Labate, B. C.; Araújo, W. S., eds., Mercado das Letras, São Paulo, pp. 661-685.

Rivera-Arce, E.; Gattuso, M.; Alvarado, R.; Zarate, E.; Aguero, J.; Feria, I. and Lozoya, X. (2007a). Pharmacognostical studies of the plant drug Mimosae tenuiflorae cortex. J. Ethnopharmacol., 113, 400-408.

Rivera-Arce, E.; Chavez-Soto, M.A.; Herrera-Arellano, A.; Arzate, S.; Aguero, J.; Feria-Romero, I.A.; CruzGuzman, A. and Lozoya, X. (2007b). Therapeutic effectiveness of a Mimosa tenuiflora cortex extract in venous leg ulceration treatment. J. Ethnopharmacol., 109, 523-528.
Sangirardi Jr. (1989), $O$ Índio $e$ as Plantas Alucinógenas. Editora Tecnoprint S.A., Rio de Janeiro.

Schultes, R. E. and Hofmann, A. (1980), The botany and chemistry of hallucinogens. Charles Thomas Publishers, Springfield.

Schultes, R. E. (1994). El campo virgen en la investigación de las plantas psicoativas. In-Plantas, Chamanismo y Estados de Consciencia. Fericgla, J. M., ed., Barcelona, La Liébre de Marzo S.L., Barcelona, 25-116.

Seigler, D. S. (2003), Phytochemistry of Acacia-sensu lato Biochem. Syst. Ecol., 31, 845-873.

Tellez, P. J. and Dupoy de Guitard, J. (1990), Pharmaceutical preparation containing Mimosa tenuiflora extract with skin-regenerating properties. Patent Eur Pat Appl. 349, 469.

Vepsäläinen, J. J.; Auriola, S.; Tukiainen, M.; Ropponen, N. and Callaway, J. C. (2005), Isolation and characterization of yuremamine, a new phytoindole. Planta Med., 71, 1053. 